\title{
Influence Service Quality, Product Quality, and Brand Image to Customer Loyalty at Club Music Center Stage Novotel Lampung
}

\author{
Susi Indriyani \\ Program Study Manajemen \\ STIE Mitra \\ Lampung, Indonesia \\ indriey2001@gmail.com
}

\begin{abstract}
Competition in the entertainment at the music club needs to be faced with the right competitive strategy, the entertainment industry in Bandar Lampung is quite well developed, this is marked by the emergence of some family karaoke, and other entertainment. Hotel Novotel Lampung as one of the four-star hotels in Bandar Lampung completes its service by providing an entertainment place called Club Music Center Stage (CMCS), in facing the business competition CMCS choose competitive strategy by seeing the influence of relationship between service, product quality and brand image with customer loyalty. The strategy is expected CMCS image will be better and can be the main choice of the clubbers who come to the city of Bandar Lampung. This study aims to determine how the influence of service quality, product quality and brand image to CMCS customer loyalty. The approach used in this research is a quantitative approach, by using a survey to collect information, the instruments used have been tested, feasible and reliable to use. The results of this study show that there is a significant direct influence simultaneously between service, product quality, and brand image with customer loyalty at Club Music Center Stage Novotel Lampung.
\end{abstract}

Keywords—quality, services, loyalty

\section{INTRODUCTION}

The development of the province of Lampung as one tourist destination is quite increased this is marked by the increasing number of tourists who enter the province of Lampung. Visits of both domestic and foreign tourists to Lampung Province in 2017 reached 8.8 million people [1]. The leading tourist attraction in Lampung Province in Lampung Bay is Anak Krakatau, Pahawang Island and Kiluan Bay which has uniqueness and outstanding natural beauty.

Consumers of music clubs are consumers with different tastes compared to consumers of other products or services. The atmosphere built in a club music is one of the key factors to the number of visitors, let's say when the music club presents a music player or a famous band the number of visitors increases and requires reservations for consumers who want to visit a music club. The effort undertaken by the music club to meet the needs of customers who come is to provide services and provision of products of good quality. This is in line with the increasing competition in the entertainment world in the city of Bandar Lampung, which began operating many family karaoke businesses and other types of entertainment. The image of the music club for some people in the city of Lampung tend to be negative, rah-rah and intoxicating liquor. These things that cause people often reject the presence of the music club until in 2015 there are several music clubs that are closed.

The CMCS music club has a large number of regular customers and comes from several segments of society. Customers remain an important asset for the company, as each customer can provide material and non-material benefits to the company. The material advantage is that the company gets the business profit from the transaction, while the non-material loan is loyal consumer will recommend the purchase and invite others to do the same transaction at the company [2]. Shanging consumer loyalty one of them by giving satisfaction There is a satisfaction that is built by instilling a relationship of service quality and good product quality.By the relationship is then the customer will prove what they have gained to be a satisfaction. The purpose of this study is to find out how the quality of service provided by the music club and the quality of the products presented and the CMCS brand image affects the customer of the music club, where the music club customer is a customer with a market segment that has unique features and characteristics. This is in line with the opinion [3] where Indonesian consumers have 10 unique characters which one of them is a consumer who likes to show off and prestige. This character will also be strengthened. Future trends will increasingly show Indonesian consumers who love to get praise from the surrounding environment for the lower community. They will exhibit the products they buy where some people can not afford them. The upper classes will pay attention to their status. They will still buy a car that gives the impression of luxury. They will buy branded products that give them a sense of pride. 


\section{LITERATURE REVIEW}

\section{A. Service Quality}

Understanding services "A service is any act or performance one party can offer to another that is essentially intangible and does not result in the ownership of anything. Its production may or not be tied to a physical product. Increasingly, manufacturers, distributors, and retailers are providing value added services, or simply excellent customer service, to differentiate themselves. Many of these statements make clear that service is any action or performance of one party offered to another that is essentially intangible and does not result in any ownership.

According Lovelock [4] Services is an economic activity offered by one party to another party. Often activities are conducted within a certain time (time-based), in the form of an activity (performances) that will bring the desired results to recipients, objects, or other assets that are the responsibility of the buyer. In exchange for money, time, and effort, service customers expect to get value from an access to certain goods, labor, expertise, facilities, networks, and systems, but customers will not usually get the property right from the physical elements involved in providing such services.

Another definition of service is the acts, actions, and processes that provide or produce by a unity or person for one entity and another [5]. With the characteristics of services such as intangibility, inseparability, variability, perishability, then consumers will be difficult to evaluate the quality of service (service quality) than the quality of goods (good quality). Quality of service should start from customer's requirement and end with customer satisfaction [6] Consumers do not evaluate only on the results, but also how they are delivered. Another definition of service is the acts, actions, and processes that provide or produce by a unity or person for one entity and another [5]

\section{B. Product Quality}

Products are everything that can be offered in the market, to satisfy the needs and desires of consumers. Products consist of goods, services, experiences, events, people, places, ownership, organization, information, and ideas, [2. According to Kotler and Armstrong [6], product quality is the ability of a product to show various functions including durability, reliability, accuracy, and ease of use.

According to Kotler and Armstrong [6], product quality is the ability of a product to show various functions including durability, reliability, accuracy, and ease of use. According to Garvin in Alma [2], to determine the dimensions of product quality, can be through eight dimensions, A product can be said to have good quality if the product is covered in eight dimensions, namely (1) Performance, (2) Features, (3) Reliability, (4) Conformance, (5) Durability, (6) Serviceability, (7) Aesthetics, (8) Perceived Quality. Given these dimensions in a product, it is expected that the product has a value more than competitors products. Building product quality is a strategic step that must be taken by the company. This is because of the quality of the product is more value or super value in the eyes of customers. The achievement of quality values is realized by building a better process and production system that can suppress the relatively cheaper cost. Therefore product quality is an effective tool for effectiveness in achieving competitive advantage.

\section{Brand Image}

Sondoh et al. [7] have studied the effect of brand image on overall satisfaction and loyalty intention in the context of color cosmetic. This study also shows that there is the positive relationship between brand image and customer loyalty. Brand image is formed from various associations that are remembered in the minds/minds of consumers when viewing or hearing a brand. According to David A. Aeker [8] brand image is a set of brand associations that are formed and embedded in the minds of consumers. Bastian [9] The results of this study variables brand image is a positive effect on brand loyalty, brand trust affects brand loyalty, brand image and significant effect on brand trust. The research was conducted on drinking water product of Ades brand packaging. Consumers also have a variety of inherent images of themselves. This self-image is closely related to the personality of the consumer, so the individual tends to buy products and services or subscribe to a brand/store that has an image or "personality" that is close to or similar to their own image. In essence, consumers try to explain themselves from the choice of brand purchased. [10] According to Shimp [11], there are three parts to the brand image measurement. The first part is the attribute. Attributes are the characteristics or aspects of the advertised brand. second is the benefit. Benefits are divided into three parts: functional, symbolic, and experience. Finally, the third part of Shimp's image measurement is the overall evaluation, the subjective value or interest that the customer adds to the consumption result.

\section{Customer Loyalty}

Basically, the purpose of a business is to create satisfied customers. The creation of consumer satisfaction can provide several benefits such as the relationship between the company and the consumer into a harmonious, providing a good basis for repeat purchase and the creation of consumer loyalty, and form a recommendation from mouth to mouth that benefits the company. Research results from Rosinta and Aryani [12] The result of the research shows that the five dimensions, i.e. physical evidence, empathy, reliability, quickness, and guaranty positively affect the service quality. The other results show that customer's satisfaction is a preceding factor of customer's loyalty. The direct effect of service quality on customer's loyalty does not sustain the research since the researcher did not find any significant direct relationship between service quality.

\section{RESULT AND DISCUSSION}

\section{A. Result}

The design of this research is quantitative descriptive research with survey technique to CMCS visitors. The research was carried out in February - July 2017 period, by distributing questionnaires to customers who are regular customers of CMCS, the sampling technique used is non 
probability sampling with judgmental sampling technique, the first research is to observe in CMCS so that the sample is 63 people. This retrieval technique is chosen because consumers are consumers who have diverse characteristics and are not easy to find or conducted in-depth interviews. Stages have been performed by testing the validity and reliability for the instruments used and the classical assumption test for determining the feasibility of the model.

From the results of the research is known the profile of respondents from total 63 respondents majority of respondents including customers who come more than 1 time in a month as much as $31.7 \%$ and the rest of respondents including customers who make 1 visit in a month with the number of $68.3 \%$. Based on the results of multiple linear regression testing obtained results as follows:

Table 1. Results of multiple linear regression test

\begin{tabular}{|c|c|r|r|r|r|r|}
\hline \multicolumn{7}{|c|}{ ANOVAb } \\
\hline \multicolumn{2}{|c|}{ Model } & $\begin{array}{c}\text { Sum of } \\
\text { Squares }\end{array}$ & df & $\begin{array}{c}\text { Mean } \\
\text { Square }\end{array}$ & F & Sig. \\
\hline \multirow{2}{*}{1} & Regression & 360.404 & 7 & 51.486 & 80.559 & .000 \\
\cline { 2 - 7 } & Residual & 35.151 & 55 & .639 & & \\
\cline { 2 - 7 } & Total & 395.556 & 62 & & & \\
\hline
\end{tabular}

This study uses significance value of 0.05 and $F$ value table of 7 independent variables and 63 respondents is 2.18 and the value of $F$ arithmetic is 80.559 . because the value of $F$ arithmetic is greater than $\mathrm{F}$ table then there is influence simultaneously between tangible, empathy, reliability, responsiveness, assurance, product quality, and brand image of CMCS customer loyalty. this is in line with the results of research Rosinta and Aryani [12] The result of the research shows that the five dimensions, i.e. physical evidence, empathy, reliability, quickness, and guaranty positively affect the service quality. The other results show that customer's satisfaction is a preceding factor of customer's loyalty. Good product quality will make consumers satisfied, brand reputation is increasing and consumers will be loyal. Product quality is one of the variables in this study that affect customer loyalty. This is in accordance with the results of research Eduardo, et al in Yuen [13] Product quality can also be a good place to start providing satisfaction and generating loyalty.

The result of $t$ test as follows:

Table 2. Results of t-test

Coefficientsa

\begin{tabular}{|c|c|c|c|c|c|c|}
\hline & \multirow[b]{2}{*}{ Model } & \multicolumn{2}{|c|}{$\begin{array}{l}\text { Unstandardized } \\
\text { Coefficients }\end{array}$} & \multirow{2}{*}{$\begin{array}{c}\text { Standardized } \\
\text { Coefficients } \\
\text { Beta }\end{array}$} & \multirow[b]{2}{*}{$\mathrm{t}$} & \multirow[b]{2}{*}{ Sig. } \\
\hline & & B & $\begin{array}{l}\text { Std. } \\
\text { Error }\end{array}$ & & & \\
\hline \multirow[t]{4}{*}{1} & (Constant) & -.846 & 1.434 & & -.590 & .558 \\
\hline & tangible & .516 & .113 & .395 & 4.550 & .000 \\
\hline & empathy & .330 & .106 & .218 & 3.104 & .003 \\
\hline & reliability & .203 & .105 & .122 & 1.935 & .058 \\
\hline
\end{tabular}

Table 2. Cont

\begin{tabular}{|c|c|r|r|r|r|r|}
\hline & responsiveness & -.181 & .091 & -.095 & -1.984 & .052 \\
\hline \multirow{2}{*}{ assurance } & .403 & .110 & .336 & 3.657 & .001 \\
\cline { 2 - 7 } productquality & .004 & .045 & .006 & .085 & .933 \\
\hline brandimage & .125 & .092 & .056 & 1.364 & .178 \\
\hline
\end{tabular}

Based on this result $\mathrm{p}$-value for tangible variable 0.000 $<0.05, \mathrm{~F}$ (count) variable p-value of $0.003<0.05$, and Assurance variable of $0.001<0.05$ means that tangible, empathy and assurance variables significantly influence customer loyalty, these three sub variables is part of service quality variable, it means that service quality plays an important role in increasing customer loyalty of CMCS Novotel Lampung, while variable of reliability, responsiveness, product quality and brand image do not influence significantly where P-value of each variable is greater than 0.05 . The amount of direct influence of tangible, empathy and assurance variables is shown by standardized coefficient beta which shows 0,395 for tangible variables, 0.218 for empathy variable and 0,218 tangible variable value into higher value variable compared with empathy variable, reliability, responsiveness, assurance, product quality and brand image.

The regression model is formed as follows:

$\mathrm{Y}=-846+0.516$ (tangible) +0.330 (empathy) +0.203 (reliability) -0.181 (responsiveness) +0.403 (assurance) + 0.004 (product quality) +0.125 (brand image)

\section{B. Discussion}

The equations are an exception to the prescribed specifications of this template. You will need to determine whether or not your equation should be typed using either the Times New Roman or the Symbol font (please no other font). To create multileveled equations, it may be necessary to treat the equation as a graphic and insert it into the text after your paper is styled.

The results showed that there was a significant direct effect simultaneously between service quality and product quality and brand image to customer loyalty at CMCS Novotel Lampung. Positive influence indicates that the higher quality of service and product quality will be higher also customer loyalty at CMCS Novotel Lampung. Similarly, the lower the quality of service, product quality and brand image the lower the customer loyalty at CMCS Novotel Lampung. Based on the result of analysis of $\mathrm{R}$ value of Square equal to 0.90 means the amount of influence given by service quality, product quality and brand image simultaneously to customer loyalty equal to $0.900=90 \%$, while $10 \%$ is determined by factors other than from those factors above. The results of this study are in line with the results of the study, Bostanji [14] The study finds that there is a strong impact of service quality (quick responsiveness, empathy and tangibility) on hotels loyalty in hotels in Riyadh. Based on the above mentioned results, a set of necessary recommendations was formulated, which enabled the hotels to strengthen the relationship between perceived service quality and customers loyalty. Providing services close to their expectations, employees training, and strengthen the culture of service quality are key factors. And in accordance with the results of research Kheng (2010) The findings show 
that improvement in service quality can enhance customer loyalty. The service quality dimensions that play a significant role in this equation are reliability, empathy, and assurance. The findings indicate that the overall respondents evaluate the bank positively, but still there are rooms for improvements.

Responsiveness variable in this research is negative, it means that if service response level in CMCS decrease will decrease service quality level. Based on the results of the observation, the service response level decreases when CMCS conducts the activity by inviting disk jockie or artist from jakarta resulting in increasing number of visitors.

\section{CONCLUSION}

Quality of service, product quality, and brand image of CMCS have a great influence on customer loyalty level, significantly influenced by tangible, empathy and assurance variables, CMCS requires improvement in service if carrying out activities with CMCS requires improvement in service if conducting activities by inviting artist from Jakarta, because the responsiveness of employees becomes lessened when there are activities.

\section{ACKNOWLEDGMENT}

The authors would like to thank STIE Mitra Lampung and the parties involved in the realization of this research.

\section{REFERENCES}

[1] Yasland, Mursalin, 2017, Jumlah Wisatawan ke Lampung Terus Meningkat,

http://nasional.republika.co.id/berita/nasional/daerah/17/11/09/oz5cxj28 0 -jumlah-wisatawan-ke-lampung-terus-meningkat, Accesed October 11, 2017

[2] Alma, Buchari. 2011, Manajemen Pemasaran dan Pemasaran Jasa, Alfabeta,Bandung.

[3] Irawan, Handi, D, 2012, 10 Karakter Unik Konsumen Indonesia, http://www.marketing.co.id/10-karakter-unik-konsumen-indonesia/ Accessed, October, 12, 2017
[4] Lovelock, Christopher, and Jochen Wirtz. 2011. Service Marketing, People, Technology, Strategy. New Jersey: Prentice Hall Upper Sadle River

[5] Zeithaml, A. Valarie, Et Al, 2013, Service Marketing, Singapore, Mc. Graw Hill Companies Inc.

[6] Kotler, philip and Kevin Lane Keller. 2009, Marketing Management, 13 Edition, PT. Glora Aksara Pratama, Jakarta: Erlangga

[7] Sondoh, S. L., Omar, M. W., Wahid, N. A., Ismail, I., \& Haru, A. 2007. The Effect of Brand Image on Overall Satisfaction and Loyalty Intention in the Context of Color Cosmetic. Journal Asian Academy of Management, 12(1): 83-107.

[8] Aaker dan David. A. 2009.Manajemen Ekuitas Merek. Edisi Pertama. Terjemahan, Jakarta: Mitra Utama.

[9] Bastian, D.A, 2014, Analisa Pengaruh Citra Merek (Brand Image) dan Kepercayaan Merek (Brand Trust) Terhadap Loyalitas Merek (Brand Loyalty) ADES PT. Ades Alfindo Putra Setia, Jurnal Manajemen Pemasaran Petra Vol. 2, No. 1, (2014) 1-9 diakses pada 20 Agustus 2017 $10.00 \quad$ WIB. http://ueu201411001.weblog.esaunggul.ac.id/wpcontent/uploads/sites/42 69/2017/03/1391-2555-1-SM.pdf

[10] Schiffman, L.G., Kanuk, L.L. 2000. Consumers Behavior 7th ed. New Jersey: Prentice-Hall, Inc

[11] Shimp, A, Terence (2003). Periklanan Promosi \& Aspek Tambahan Komunikasi Pemasaran.Terpadu, Jilid I ( edisi 5), Jakarta: Erlangga.

[12] Aryani, Dwi, Febrina Rosinta, 2010, Pengaruh Kualitas Layanan terhadap Kepuasan Pelanggan dalam Membentuk Loyalitas Pelanggan, Bisnis \& Birokrasi, Jurnal Ilmu Administrasi dan Organisasi, MeiAgus 2010, hlm. 114-126 ISSN 0854-3844 Volume 17, Nomor 2. http://journal.ui.ac.id/jbb/article/view/632/617 accessed, 22 August $\underline{2017}$

[13] Yuen, Euphemia, F. T and Sian S L Chan, 2010, The effect of retail service quality and product quality on customer loyalty, Journal of Database Marketing \& Customer Strategy Management, September 2010, Volume 17, Issue 3-4, pp 222-240, https://link.springer.com/article/10.1057/dbm.2010.13 diakses pada 10 Agustus 2017, pukul 10.00 WIB.

[14] Bostanji, Galib Mohammed Al.2013,The Impact of Service Quality on Customers Loyalty, A Study on five stars hotel's customers in Riyadh, KSA, European Journal of Business and Management, ISSN 2222-1905 (Paper) ISSN 2222-2839 (Online),Vol.5, No.31, 2013. http://www.iiste.org/Journals/index.php/EJBM/article/viewFile/9491/96 85 . 